\title{
INTERPERSONÁLNÍ HYPOTÉZA HUDBY A HLUBINNĚ HERMENEUTICKÉ HLEDÁNÍ SMYSLU UMĚLECKÉHO DÍLA
}

Jedním z originálních př́nosů české hudební vědy s mezinárodním dosahem je interpersonální hypotéza hudby (umění). Při zpětném pohledu z pozice dnešních dnů je specifické, že uvedená hypotéza byla formulována a dále rozvíjena výrazně interdisciplinárním způsobem, provázeným vysokou mírou celkové propracovanosti a aplikabilitou v řadě oblastí. Původní prostřední psychiatrie, psychologie a psychoterapie, v nichž byla hypotéza původně formulována v roce 1964 Ferdinandem Knoblochem (1916) v rámci jeho integrované psychoterapie, se posléze rozšiřují o muzikologickou reflexi jeho spolupracovníků Milana Poštolky (1932 -1993) a dalších, ale také o impulzy etologie, sémiotiky, hudební antropologie. Vlastní muzikologický rozvoj hypotézy je spjat od konce 60. let minulého století s osobností Jarmily Doubravové (1940) v oblasti dalšího experimentálního ověřování $\mathrm{v}$ hudební recepci, ale zvláště prováděnými interpersonálními analýzami hudebních skladeb. Je zásluhou právě uvedené J. Doubravové, že se vývoj interpersonální hypotézy mohl prezentovat domácí odborné veřejnosti vzhledem $\mathrm{k}$ diskontinuitě působení $\mathrm{F}$. Knoblocha $\mathrm{v}$ tehdejším Československu, který v roce 1968 emigroval do Kanady. ${ }^{1}$ O významu pojednávané teorie svědčí také řada publikačních a konferenčních výstupů Doubravové v zahraničí a jejich pozitivní přijetí. Formulování a prohlubování podoby hypotézy opsalo časově klenutý oblouk od svých počátků v 60 . letech, provázející její ověřování na materiálu hudby baroka až 20. století, pokračovalo v dalších dvou desetiletích rozvojem analytických studií J. Doubravové (odkažme alespoň na skladby Leoše Janáčka, Josefa Suka, Albana Berga, Bély Bartóka). V 90. letech bylo provedeno další praktické ověřování (mj. na skladbách českých autorů 20. století: Bohuslav Martinů, Iša Krejčí, Jan Rychlík, Miloslav Kabeláč aj.) a aktualizace celé hypotézy v podobě nových studií F. Knoblocha i J. Doubravové s přesahem do současnosti.

Tento text není směřován $\mathrm{k}$ deskripci geneze interpersonální hypotézy a jejímu hodnocení v kontextu muzikologie. Jeho snahou je upozornit na některé z možných

1 Odkažme alespoň na vybrané studie Jarmily Doubravové v časopisech Hudební věda a Opus musicum (viz Bibliografii). 
interpretačních podob jejího chápání, které mají blízko k hermeneutickému přístupu k umění, a to i přes to, že východiskem hypotézy je de facto hudební sémiotika. Vodítkem nám jsou kategorie významu a smyslu, ale i symbolu, archetypu analytické psychologie Carla Gustava Junga (1875-1961), či sémantického gesta, dotvárející diferencovaný obraz jádra této teorie. Jednou z hlavních myšlenek našeho vztahování se $\mathrm{k}$ analytické metodě interpersonální hypotézy je sledování způsobu odhalování některých základních principů utváření hudby v návaznosti na archetypické procesy a antropologické konstanty psychiky člověka, pojmenovávané např. již v antice a mýtu, a kterým se v průběhu novodobého vývoje věd dávaly různé názvy. Tyto obecné principy jsou mj. důvodem, proč umění obecně zakoušíme jako smysluplné, naplněné významem.

Pro výše definované cíle zde ve stručnosti připomeňme některá základní fakta a skutečnosti. Interpersonální hypotéza vychází z prokázané existence interpersonálních tendencí v projevech individua a „komunikativní povahy uměni", ${ }^{\prime \prime}$ je př́spěvkem $\mathrm{k}$ významovosti hudby a povaze tohoto významu. Pro vznik interpersonálních tendencí mají zásadní význam tzv. malé sociální skupiny, jejichž prostřednictvím se utváří naše „skupinové schéma“, mj. sloužící k orientaci v životě a řešení problémů. Interpersonální tendence lze identifikovat nejen v materiálu snu, denního snění, halucinací, ale také v umění, vychází se zde z přirozeného uspokojování interpersonálních potřeb skladatele i posluchače (př́ijemce, interpreta apod.). Individuálně odlišný obsah hudebního zážitku má proto společné rysy díky univerzálnímu významu hudby ve vymezeném smyslu, i když plně nevyčerpává jeho obsah. Interpersonální povaha hudebního zážitku má vzhledem $\mathrm{k}$ těmto tendencím fantazijní charakter, nebot', „[...] jedním ze závažných aspektů hudebni zkušenosti je fiktivní pohyb v interpersonálním prostoru, účast na fantazijním interpersonálním ději, [...] interpersonální tendence jsou důležitými signifikáty hudební řeči. “3 Knoblochovo vymezení hypotézy proto zní: „v různých hudebnich skladbách různých dob se projevuji interpersonální tendence a nezávisli posuzovatelé je mohou identifikovat se shodou, jež se vymyká náhodě. “" V prvních fázích výzkumu bylo použito osm hlavních interpersonálních tendencí podle Timothy F. Learyho (Interpersonal Diagnosis of Personality z roku 1957), později bylo jejich použíání a klasifikace pod vlivem impulzů z etologie (Konrad Lorenz) a evoluční biologie Knoblochem upraveno do následující podoby jako cirkumplex: $+\mathrm{A}$ afiliace, $-\mathrm{A}$ distance, $+\mathrm{F}$ agrese, $-\mathrm{F}$ útěk, $+\mathrm{D}$ dominance, $-\mathrm{D}$ submise, + E exhibice plus, - E exhibice minus. Součástí těchto tendencí jsou rozpoznatelné role skupinového schématu: autorita, souřadný subjekt, erotický objekt a podřízení. Hudba na základě uvedeného ikonicky signifikuje interpersonální tendence subjektu i „generalizovaného druhého“, denotuje fantazijní inter-

2 KNOBLOCH, Ferdinand - POŠTOLKA, Milan - SRNEC, Jan. Hudební sémantika z interpersonálního hlediska. Hudební věda, 1965, roč. 2, č. 1, s. 271. Srov. další Knoblochovy studie v Bibliografii.

3

Ibid., s. 272.

4 Ibid. 
personální děj, a to neverbálním gestickým a posturickým způsobem. Participace posluchače a skladatele na interpersonálním schématu nemusí být vždy vědomá. Předpokladem nastíněného procesu je, že se náš duševní život promítá do hudby a s tímto prostorem můžeme vést dialog, byt' cestou fiktivní manipulace sdílených skupinových schémat.

Interpretační rozměr sledovaného tématu rozvedeme ve vztazích autor hudebního díla - hudební dílo - př́ijemce s odkazem na rozlišení těchto pojmů umění interpretace dle Umberta Eca, tj. intentio autoris, intentio lectoris a intentio operis. ${ }^{5}$ Interpersonální hypotéza vychází z imaginativního děje, který interpretačně můžeme $\mathrm{v}$ díle zakoušet. $\mathrm{Z}$ hermeneutického hlediska je celý proces interpretačně podnětný. Pracuje s fiktivním (fantazijním) prostorem a interpersonálním děním, ustanovuje se zde dialog ,jiného“ s autorským či vlastním (uměleckým) ,já“. $\mathrm{K}$ vytváření tohoto dění dochází u skladatele skrze tvorbu díla. Více či méně zřetelně formulovaným předpokladem zde je, že se interpersonálního prostoru skladatele lze posléze dobrat a rekonstruovat jej při vědomí estetické distance. ${ }^{6}$ To by hypoteticky znamenalo, že interpersonální tendence jsou přítomny v díle (jsou vyjádřitelné pomocí vyjadřovacích prostředků hudby) a posluchač s nimi dialogicky manipuluje a dobírá se jich na základě symbolizačních procesů v hudbě. Interpersonální př́istup zohledňuje i hermeneutické determinanty vzniku díla, historické okolnosti, osobnostní charakteristiky skladatele apod., ale o ně nejde primárně. $\mathrm{Na}$ druhou stranu se lze tázat, zda nejsou interpersonální tendence empiricky nacházeny ve shodě mezi posluchači právě na základě sdílení těchto tendencí lidskou psychikou. Nemusí nutně jít o rekonstrukci skladatelova interpersonálního schématu, ale o společnou participaci na tomto dění, která je i přes jasnou kulturní podmíněnost našeho styku s uměním sdílená, pro člověka konstitutivní a ontologicky a priori daná.

Interpersonální hypotéza má svým důrazem na vcítění a rozumění $\mathrm{k}$ hermeneutice blíže, než by se při prvním pohledu na její sémiotická, psychologická, empiricky ověřitelná východiska zdálo. Je to dáno její citelnou otevřeností $\mathrm{k}$ hudebnímu významu, vstřícností vůči jiným teoriím, nedefinitivně ukončené podobě výsledků (projev ,putujícího subjektu“), stejně tak nedeklaruje, že ji lze aplikovat na všechny hudební projevy a pojetí umění. Interpersonální hypotéza zohledňuje celý proces rozumění, uvědomování si vlastních předsudků při interpretaci, a to způsobem archetypicky dialogickým, odhalujícím se v komunikaci s cizí či vlastní kulturou nebo autorským subjektem. Nadindividuální symbolický charakter interpretace se zde poodhaluje prítomností „kompetentního posluchače“" či celkově hlubinně psychologickým dialogem, v čemž je již přítomen

5 Srov. ECO, Umberto. Meze interpretace. 1. české vyd. Praha: Univerzita Karlova, nakladatelství Karolinum, 2004.

6 V analýze Houslového koncertu A. Berga je dle Doubravové cílem „hloubkové proniknuti dila, rekonstrukce autorova záméru." DOUBRAVOVÁ, Jarmila. Houslový koncert Albana Berga z interpersonálního hlediska. Hudebni věda, 1972b, roč. 9, č. 2, s. 117. z roku 1953) nebo o požadavku „kompetentního posluchače“ v kontextu hudební narativity 
smysl, určitá intence: „dialog s alter ego-stínem, dialog s animou-nesmrtelnou milenkou nebo s věčnou matkou. [...] Dialogičnost hudby závisí na zjevných i skrytých mechanismech jejího tvořeni a posloucháni. " 8 Doubravová se kriticky staví proti reziduím hudebního realismu (s odkazem na středověký realismus v teologii) v podobě fikce „pravdivosti“, samospasitelnosti „struktury“ a př́lišné akcentaci struktury nad posluchače $\mathrm{v}$ abstrahované podobě od lidského života, fikce jediné správné teorie. Specifičnost takto chápané hudby vede k výlučnosti, nekomunikativnosti. ${ }^{9}$ Jak autorka dále píše: „Na základě procesu identifikace a distance, tedy (do jisté míry) metodou vcitění, lépe sebepoznávání, nejpřesněji stálého symbolického dialogu, se z posluchače stává interpret $i$ autor, respektive alter ego autora (současně si uvědomuje i vlastni alter ego). " ${ }^{10}$ Interpersonální analýzy J. Doubravové představují snahu o vyvažování nezbytného strukturního pohledu na hudbu aspektem významu, kterému rozumíme, ale také chápáním smyslu hudby cestou intuitivní, imaginativní, dialogickou ${ }^{11}$. Hovoř́me zde proto o dialogickém rozvíjení řeckých principů „logos“ (zde rozum, struktura), ale i „telos“, tj. vnitřní logika díla s intencí a obrazem, do kterých se v analýze a interpretaci noříme, zpř́itomňujeme smysl a možnost jeho sdílení. Charakteristický akcent interpersonální hypotézy hudby na otevřenost interpretace a na roli posluchače bez prŕlišného lpění na „objektivní“ struktuře hudby anticipoval tuto tendenci od 70 . let 20 . století v uměnovědách a estetice. ${ }^{12}$

Dalším významným momentem je formulování doplňující hypotézy J. Doubravové ze 70 . let o korespondenci mezi interpersonálními tendencemi a hudební formou: ,formová schémata pravděpodobně představuji modelové situace, které se ve vývoji hudby stabilizovaly, zobecněly a prešly do znakového systému hudby.“"13 Hudební formy Doubravová chápe jako ,zobecnělé a zestereotypizované retězce expresivnich vzorců chováni. “14 Při detailnější analýze dále rozlišuje

Eera Tarastiho (Theory of Music Semiotics, 1994). DOUBRAVOVÁ, Jarmila. Dialog a imaginace. Interpersonálni hypotéza uměni(m). 1. vyd. Praha: Editio Supraphon, 1998, s. 74, 141-147.

8 DOUBRAVOVÁ, Jarmila. Sémantické gesto. 1. vyd. Praha: Univerzita Karlova v Praze, Karolinum, 2001, s. 22.

9 DOUBRAVOVÁ, op. cit. (1998), s. 140-141.

10 Ibid., s. 163.

11 Dialogické charakteristiky našeho tvořivého styku s uměním v procesu vytváření lidské kontinuity a integrity identifikuje Zuzana Sláviková v následujícím článku. SLÁVIKOVÁ, Zuzana. Dialóg ako základná premisa l’udskej existencie. In Filozoficko-estetické reflexie posthistorického umenia. Jana Sošková (ed). Prešov: Filozofická fakulta Prešovskej univerzity v Prešove, 2008, s. 469-477.

12 Jde o přenesení významu na roli posluchače a jeho interpretační zacházení s uměním, pragmatický aspekt toho, jak se hudba „chová“"k vnímajícímu subjektu. Srov. DOUBRAVOVÁ, Jarmila. Interpersonální aspekt v hudebním vyjadřování a sdělování. Opus musicum, 1972a, roč. 4, č. 8-9, s. 254-258.

13 DOUBRAVOVÁ, Jarmila. Interpersonální význam hudby a hudební sémiotika. Hudební véda, 1975, roč. 12, č. 2, s. 159.

Ibid. 
vzorce, figury a řetězce interpersonálních tendencí, které korespondují s hudební formou jako modely hudební komunikace. Doplňující hypotéza nenarušuje uměleckou svébytnost vývoje hudby v oblasti tektoniky a hudebních forem evropské artificiální hudby, ale poukazuje na obecné principy umělecké tvorby ve vazbě na psychiku člověka; na ty principy a tendence, které předcházejí a podmiňují uměleckou tvorbu a její recepci. Tímto se dostáváme k tektonickým archetypům, „věčným návratům“, invariantům jako opakování, kontrast, obměna, jejichž projevy jsou zaznamenatelné i v př́ipadě jungovských archetypů a jejich symbolizačních projevů $\mathrm{v}$ umění. ${ }^{15} \mathrm{~V}$ nastíněném kontextu uvedené analogizujeme se známou analýzou mýtů jihoamerických indiánů Claudem Lévi-Strausem ( Le Cru et le cuit, 1964), identifikující podobnost mezi formou mýtů a hudebními formami: fuga, sonáta, variace, invence, symfonie aj. ${ }^{16}$ Poukažme na tyto formy mýtu, které zde byly před počátkem utváření novověkých hudebních forem. V hudbě 20. století se navíc setkáváme s oživováním mytologických principů a symbolů v souvztažnosti s novými formovými i tektonickými principy. ${ }^{17}$ Vazbu interpersonálních tendencí a hudebních forem proto chápeme jako archetypickou: pronikání archetypických forem do kolektivního vědomí vede k jejich postupné stabilizaci, projevy archetypů lze interpretovat interpersonálně a zároveň z muzikologického hlediska. Podobně jako archetypy jsou interpersonální tendence v průběhu času normalizovány v podobě kulturních kánonů a mohou se ve svých projevech transformovat - nejsou neměnné $\mathrm{v}$ projevech invariantního základu. V kulturním a uměleckém kánonu dané doby se konfigurují archetypy a symboly, dochází $\mathrm{k}$ vědomému udržování jejich projevů fixováním (norma, tradice), jak můžeme identifikovat $\mathrm{v}$ proměňujících se vlastnostech jednotlivých uměleckých stylů. Erich Neumann v díle Art and the Creative Unconscious ${ }^{18}$ popisuje svět kulturních kánonů jako transpersonální, $\mathrm{k}$ desintegraci a opětovnému vznikání archetypů dochází vynořováním nových archetypických konfigurací z kolektivního nevědomí. Tato vnějším způsobem se projevující progrese v uměleckých formách je realizována skrze tvořivé individuum a jeho napojení na kolektivní nevědomí, i když je samotné rozpracování umělecky stylových impulzů záležitostí vědomé a racionální práce. Archetypální konfigurace (např. v umění) může být jedincem zakoušena jako pocit numinozity a výlučnosti. Zde opět vidíme vztah s interpersonálními tendencemi. Interpersonální pohyb v hudbě nás může oslovit, jeho prostřednictvím uspokojujeme své potřeby, identifikujeme se s ním, stejně tak jej můžeme odmítnout, zaujmout distanci, popř. nechat se vést tendencemi dle vybavenosti posluchače s obdobnými účinky jako v príípadě archetypických symbolů.

15 Srov. KOZEL, David. Antický hudebni mýtus. 1. vyd. Ostrava: Ostravská univerzita v Ostravě, 2012, s. 7-45.

Viz LÉVI-STRAUSS, Claude. Mythologica* : syrové a vařené. 1. vyd. Praha: Argo, 2006. berg to Schnittke and Crumb. 1. vyd. NY, Hillsdale: Pendragon Press, 2007.

18 NEUMANN, Erich. Art and the Creative Unconscious. Four Essays. 1. vyd. New York: Bollingen Foundation Inc., 1959, s. 108-109. 
Vztah interpersonálních tendencí a hudebních forem dokládáme také kategorií sémantického gesta a jeho projevu v hudbě. Interpersonální tendence představují v tomto významu denotáty pohybových tendencí v imaginárním prostoru. Sledované tendence jsou v hudbě př́tomny mj. na základě intencionálního (vědomého či nevědomého) výběru kompozičních prostředků skladatelem a následně jsou takto vnímány i posluchačem. V hudbě se popsané týká motorického gesta, zvukové stránky verše a hudby a vlastního sémantického gesta; je to výběr výrazových prostředků, materiálu s doprovodným pohybem v mysli autora i posluchače. U Jana Mukařovského je sémantickým gestem myšlen základní princip, na kterém spočívá významová jednota básnického (uměleckého) díla, společný jmenovatel složek díla (tj. význam). Je to obsahově nespecifikovatelné gesto, provázené významovou jednotou ve výstavbě a volbou a slučováním prostředků struktury díla. ${ }^{19}$ Týká se nejen struktury, ale také smyslu díla, který vnitřně organizuje a ukazuje směr hledání tohoto smyslu. Interpersonální hypotézu hudby proto můžeme podle Doubravové zařadit do linie vývoje sémantického gesta u Jana Mukařovského (Pražského lingvistického kroužku, včetně Gustava Beckinga), linie hermeneutické teorie rozumění (Wilhelm Dilthey, vcítění), v hudbě konkrétně u Otakara Hostinského a Otakara Zicha (pojem „významová představa“), nebo v př́padě estetických experimentů Antonína Sychry a Karla Sedláčka. ${ }^{20}$

Dalším momentem prezentované reflexe interpersonální hypotézy je již zmíněné sémioticko-pragmatické východisko v referenci na Charlese W. Morrise (1901-1979). Z historického pohledu hypotéza představovala a představuje potřebné metodologické doplnění a oživení směřování české hudební sémiotiky, která ve svém většinovém proudu využívala a aplikovala především sémiotickou koncepci Charlese Sanderse Peircea (1839-1914). ${ }^{21}$ Konsekvencí bylo dominantně rozvíjené a posléze utvrzované pojetí symbolu jako konvencionalizovaného znaku a jeho určení subjektem. V interpersonální hypotéze je symbol chápán mnohovrstevnatě a otevřeně ve vztahu s dynamikou interpersonálního dění a takto chápanou symbolizací. Myšlenkově je signifikantní blízkost s odlišnou teoretickou linií: s hudební hermeneutikou Arnolda Scheringa, filozofíi symbolických forem Ernsta Cassirera, s tezemi Suzanne Langerové o hudbě jako „mýtu našeho vnitřního života“, hudební antropologií Alana P. Merriama, nebo s Jungovým chápáním symbolu s nejednoznačným, neukončeným význam a smyslem, který není sdělitelný př́mo, ale pouze skrze interpretaci jeho projevu. Tyto teze dokládá např. následující citace ze studie J. Doubravové k hudební symbolice: „Vycházi totiž [interpersonální hypotéza, pozn. D. K.] z pojetí umění jako fantazijniho řešení existenciálnich problémů, tedy z pojetí umění jako symbolické

19 GRYGAR, Mojmír. Terminologický slovník českého strukturalismu. 1. vyd. Praha: Host, 1999, s. 222-229.

20 DOUBRAVOVÁ, op. cit. (2001), s. 9-17.

21 Jde např. o triadické chápání znakovosti a syntaktický a sémantický důraz na hudební strukturu. Viz práce Pražského týmu pro hudební sémiotiku. 
aktivity - tedy konec konců - z pojmu symbolu. “22 $\mathrm{V}$ námi opakovaně naznačeném hermeneutickém pozadí interpersonální hypotézy hudby lze na základě jmenovaných obsahů (symbol, vnitřní intence hudebního díla ve spojitosti se sémantickým gestem, vztah interpersonálních tendencí s hudebními formami, archetypy) upozornit na prodloužení tohoto myšlenkového hledání uvnitř uměnovědné hermeneutiky např. u Miroslava Mikuláška, když identifikuje rodokmen umění interpretace směrem k antickým počátkům: ,aitia eidetiké" (Aristotelés), „tó endon eidos“ - „vnitřní forma“ (Plotínos), univerzální hermeneutický koncept sv. Augustina „verbum interius“, tj. jeho niterné „verbum cordis“. 23

Interpersonální hypotéza se ukazuje být velmi živoucím analytickým nástrojem i v dnešní době globalizace a postmoderny, v níž se nastolují nejednoznačně řešitelné otázky interpretace hudby. Jak se v této situaci vztahujeme $\mathrm{k}$ hudební tvorbě „jiné" kultury, jak zakořeněné a pevné je naše vědomí kulturní tradice (konstituující interpersonální ,jä“), je možné interpersonální porozumění skrze umění? To nás může vést $\mathrm{k}$ otevírání dialogu, ale i k potřebě utvrzování a prohlubování vědomí vlastní tradice. Interpersonální hypotéza upozorňuje na existenci univerzálních principů umění, stojících v pozadí našich kognitivních a imaginativních potencí. Je to prostředek, jak naše poznání scelovat, dávat mu jednotu, smysl a dialogicky se tázat, nikoliv pouze uvnitř jedné teorie, kterou vytváríme pro ni samotnou. Ferdinand Knobloch ve studii The Interpersonal Meaning of Music and Ethology z roku 1995, v níž se navrátil k opětovnému promýšlení své hypotézy, uvádí: „Interpersonální analýza hudby nám může přinést nejen bližší porozumění hudby a umění, ale také bližší porozumění hlubin lidské přirozenosti." ${ }^{\text {"24 }}$

David Kozel (david.kozel@osu.cz), Katedra hudební výchovy, Pedagogická fakulta, Ostravská univerzita v Ostravě.

\section{ABSTRACT \\ THE INTERPERSONAL HYPOTHESIS OF MUSIC AND A DEEP HER- MENEUTIC SEARCH FOR MEANING IN A WORK OF ART}

The interpersonal hypothesis of music presents an original contribution to Czech musicology dating back to the $1960 \mathrm{~s}$. This paper focuses on the wider interpretation of the principle of the hypothesis in relation to deep hermeneutic thought. The principle of the hypothesis is interpreted based on the work of Ferdinand Knobloch and Jarmila Doubravová. The discovery of meaning

22 DOUBRAVOVÁ, Jarmila. Symbol v hudbě a muzikologii. In Symbol v lidském vnímání, myšlení a vyjadřování. Praha: Filozofický ústav ČSAV, 1992, s. 247.

23 MIKULÁŠEK, Miroslav. Via cordis: ars interpretetionis hermeneuticae. 1. vyd. Ostrava: Filozofická fakulta Ostravské univerzity v Ostravě, 2011, s. 14.

24 Vlastní překlad. „Interpersonal analysis of music may bring us not only closer to the understanding of music and arts, but also to the understanding of the depths of human nature." KNOBLOCH, Ferdinand. The Interpersonal Meaning of Music and Ethology. ASCAP [online], 1995, vol. 6, no. 7 (revised 2000). [cit. 2014-09-27]. Dostupné z:

${ }^{<}$http://cogweb.ucla.edu/Abstracts/Knobloch_95.html $\geq$ 
in a musical work is the result of a dialogic process with the deep contents of our conscious and unconscious. Symbolization of the archetype does not occur only in metaphorical material, but the musical stream and its events can take on meaning for an individual in relation to a universal as well as individual aesthetic experience. The invariant of interpersonal tendencies in music is, for this reason, in affinity to archetypal situations.

\section{Key words}

interpersonal hypothesis of music, Jarmila Doubravová, Ferdinand Knobloch, archetype, deep hermeneutics, semantic gesture, music symbolism

\section{Bibliography}

ADAMENKO, Victoria. Neo-Mythologism in Music. From Scriabin and Schoenberg to Schnittke and Crumb. 1. vydání. NY, Hillsdale: Pendragon Press, 2007.

DOUBRAVOVÁ, Jarmila. Interpersonální hypotéza v hudební sémiotice. Hudební věda, 1970, roč. 9, č. 2, s. 179-183.

DOUBRAVOVÁ, Jarmila. Interpersonální aspekt v hudebním vyjadřování a sdělování. Opus musicum, 1972a, roč. 4, č. 8-9, s. 254-258.

DOUBRAVOVÁ, Jarmila. Houslový koncert Albana Berga z interpersonálního hlediska. Hudební věda, 1972b, roč. 9, č. 2, s. 117-139.

DOUBRAVOVÁ, Jarmila. Interpersonální význam hudby a hudební sémiotika. Hudební věda, 1975 , roč. 12, č. 2 , s. 154-164.

DOUBRAVOVÁ, Jarmila. Symbol v hudbě a muzikologii. In Symbol v lidském vnímání, myšlení a vyjadřování. Praha: Filozofický ústav ČSAV, 1992, s. 242-248.

DOUBRAVOVÁ, Jarmila. Dialog a imaginace. Interpersonální hypotéza umění(m). 1. vyd. Praha: Editio Supraphon, 1998.

DOUBRAVOVÁ, Jarmila. Sémantické gesto. 1. vyd. Praha: Univerzita Karlova v Praze, Karolinum, 2001.

ECO, Umberto. Meze interpretace. 1. české vyd. Praha: Univerzita Karlova, nakladatelství Karolinum, 2004.

GRYGAR, Mojmír. Terminologický slovník českého strukturalismu. 1. vyd. Praha: Host, 1999.

KNOBLOCH, Ferdinand - POŠTOLKA, Milan - SRNEC, Jan. Musical Experience as Interpersonal Process. A Contribution to the Semantics of Music. Psychiatry, 1964, vol. 27, no. 3, s. 259265.

KNOBLOCH, Ferdinand - POŠTOLKA, Milan - SRNEC, Jan. Hudební sémantika z interpersonálního hlediska. Hudebni věda, 1965, roč. 2, č. 1, s. 271-277.

KNOBLOCH, Ferdinand - JUNA, Jaromír - JUNOVÁ, Hana - KOUTSKÝ, Zdeněk. On an interpersonal hypothesis in the semiotic of music. Kybernetika, 1968, vol. 4, no. 4, s. 364-382.

KNOBLOCH, Ferdinand. The Interpersonal Meaning of Music and Ethology. ASCAP [online], 1995, vol. 6, no. 7 (revised 2000). [cit. 2014-09-27]. Dostupné z:

$<$ http://cogweb.ucla.edu/Abstracts/Knobloch_95.html $\geq$

KOZEL, David. Antický hudební mýtus. 1. vyd. Ostrava: Ostravská univerzita v Ostravě, 2012.

LÉVI-STRAUSS, Claude. Mythologica* : syrové a vařené. 1. vyd. Praha: Argo, 2006.

MIKULÁŠEK, Miroslav. Via cordis: ars interpretetionis hermeneuticae. 1. vyd. Ostrava: Filozofická fakulta Ostravské univerzity v Ostravě, 2011.

NEUMANN, Erich. Art and the Creative Unconscious. Four Essays. 1. vyd. New York: Bollingen Foundation Inc., 1959.

SLÁVIKOVÁ, Zuzana. Dialóg ako základná premisa l’udskej existencie. In Filozoficko-estetické reflexie posthistorického umenia. Jana Sošková (ed). Prešov: Filozofická fakulta Prešovskej univerzity v Prešove, 2008, s. 469-477. 